\title{
Presence and Formation of Adults in the Sodality of Our Lady: Contribution to the Native History
}

Although this issue seems to be known, there are, few studies especially when it comes to the Sodalities (aka Congregations) of Our Lady in the period before the eighteenth century dissolution of the Society of Jesus. Before addressing the issue of the presence and formation of adults in those Congregations, it is worth taking a brief look at the history of the Marian Sodality (the Sodality of Our Lady) $)^{2}$. This article focuses on the formation and self-formation of the adult people, at first in the ranks of the Marian Congregation and then, particularly, the Christian Life Community as the continuator of the Jesuit Marian Congregation ${ }^{3}$.

\footnotetext{
1 Justyna Sprutta - $\mathrm{PhD}$ in dogmatic theology (a specialisation: the icon theology), $\mathrm{PhD}$ in history (a specialisation: the art history), a graduate of Polish philology. She also is the academic teacher at the Faculty of Theology (Adam Mickiewicz University in Poznań) and the Academy of Finanse and Buisness "Vistula" (in Pultusk), and a librarian in Strzyżew. She is a member of the Polish Institute of World Art Studies and the Poznan Society for the Advancement of Arts and Sciences; e-mail: justynasprutta@o2.pl. ORCID: 0000-0001-9949-9953.

2 More about the Marian Sodality, e.g.: com. K.M. Morawski, 350 lat duchowej sodalicji w świecie, a w szczególności w Polsce, "Przegląd Powszechny" 205 (1935), pp. 331-340; J. Flaga, Bractwa i sodalicje jezuickie w Polsce w 2 pot. XVIII w., "Summarium" 3 (1974), pp. 144-148; idem, Z problematyki jezuickich bractw i sodalicji w XVIII wieku, in: Państwo, Kościól, niepodlegtość, red. J. Skarbek, J. Ziółko, Lublin 1986, pp. 171-187; idem, Sodalicje w Polsce przed kasata zakonu, in: Encyklopedia wiedzy o jezuitach na ziemiach Polski i Litwy 1564-1995, red. L. Grzebień, Kraków 1996. The Congregation edited also own magazine: "Sodalis Marianus". Access to periodic numbers surviving from the twenties of XX century interwar period: https://www. wbc.poznan.pl/dlibra/results? $\mathrm{q}=$ sodalis + marianus\&action $=$ SimpleSearchAction $\&$ type $=-6 \& \mathrm{p}=0$ [access: 19.08.2020].

${ }^{3}$ Wider on the Christian Life Community: com. https://www.wzch.org.pl/ [access: 19.08.2020].
} 


\section{The history of the Sodality}

The founder of the Marian Sodality (aka the Marian Congregation) was the Belgian Jesuit John Leunis. He initiated it in 1563 at the Collegium Romanum in the Eternal City (Congregatio, aka Sodalitas Primaria B. Virginis Mariae aka Primaria Congregatio Mariana). The Marian Sodality was canonically approved as the Roman College Congregation by Pope Gregory XIII the papal bull Omnipotentis Dei of December 5, 1584. Furthermore, the pope granted it with the right of affiliation and this way contributed to dynamic development of the Sodality groups. Moreover, he allowed the General of Jesuits, Claudius Aquaviva to form Congregations in colleges outside Rome and to aggregate them into the Roman Sodality. In addition, he 'endowed' Primaria Congregatio Mariana with privileges, such as indulgences.

Much later, in 1746, Pope Benedict XIV approved the statute of the Marian Sodality with the bull Gloriosae Dominae of September, 27. When it comes to C. Aquaviva, it should also be added, that in 1587 the general developed a statute, binding all the Sodalities without exception. The statute was probably modelled on the first rules created by J. Leunis. From that moment on, the Sodalities, scattered around the houses and monastic colleges, started to exist as a public and ecclesiastical union, governed by the cannon law. Thanks to the bull Superna dispositione (of January 5,1587 ) of Pope Sixtus V, it was possible for C. Aquaviva to extend the privileges to the Sodalities created at all Jesuit colleges. Furthermore, the general, after J. Leunis had left the Sodalities with full independence in the election of the board, during the twenty years of the Congregation's existence became convinced of the effectiveness of centralized management in the Sodalities. Therefore, he decided among other matters, that the principal of the Sodality (moderator, in the case of the Christian Life Community an ecclesial assistant) would be appointed by the superior (the principal of a religious house) priest Jesuit. And also, by the will of the superior, not on the initiative of the laity, the Sodalities were to be established at the religious houses.

In the native lands there was a very vigorous development of the Sodalities in the $17^{\text {th }}$ and $18^{\text {th }}$ centuries. In the Age of Enlightenment admit girls began to officially be admitted in the Sodality ranks. The dynamic evolution of the Congregation lasted until the dissolution the Society of Jesus that was taking care of the Sodalities. The dissolution was performed by Pope Clement XIV on July 21, 1773 breve Dominus ac Redemptor. The period after the dissolution but before the revival of the Society of Jesus, i.e. the years 1773-1814, changed the image of the Sodality: many Congregations, cut off by the decision of the Holy See from the sources of Ignatian spirituality, began to disintegrate. Indeed, according to the will of the above-mentioned Pope they were still able to function, but only under the jurisdiction of local bishops. Nevertheless, as a consequence of the isolation, 
they became completely different Congregations. Only in Russia they still developed as a piece of Jesuit work, but only because Tsarina Catherine II did not accept and announce the papal decree on the dissolution of the Society of Jesus.

With the moment of rebirth, thanks to Popes Pius VI and Pius VII of the Jesuit Order, the Sodalities began to return under the patronage of the Society of Jesus, but still they did not regain their original face. Katarzyna Czarnecka writes, 'The decision to restore the order in 1814 did not change the situation, since the Sodalities, responding to the social needs of the time, became a religious mass movement as one of the works of the universal Church'4. The first Congregation established after the reactivation the Society of Jesus in the home area was the Marian Sodality in Stary Sącz (1839).

Indeed, ten years after the 'resurrection' of the Society of Jesus, i.e. in 1824, Roman Prima Primaria returned under the Jesuit Order leadership, but due to the low number of Jesuit priests, the general of the Society of Jesus, Aloysius Fortis, asked by Pope Leo XII, in 1825 allowed to divide the Sodalities into two different branches joined only by the act of canonical aggregation to Prima Primaria. The first branch constituted the Sodalities belonging to Jesuit houses and churches, while the second branch constituted the Sodalities attached to other churches and chapels subject to the diocesan clergy, and not the Jesuits. With time, the Sodalities also came under the care of orders other than the Jesuits, e.g. the Piarists, the Paulites, the Ursulines or the Sisters of Our Lady of Mercy. It is worth adding that when the Society of Jesus ceased to exist, the Sodalities, although not numerous at the time, survived under the care of ex-Jesuits, other friars and diocesan priests, but most of the Congregations collapsed anyway. It should also be emphasised that they began to evolve especially vigorously after the proclamation of the Dogma about the Immaculate Conception of the Blessed Virgin Mary by Pope Pius IX in 1854. After about eighty years from that moment, namely in 1930, there were 58 thousand Sodalities all around the world, associating over 2.5 million Catholics under the care of the Jesuits and the diocesan clergy ${ }^{5}$. Their development was stopped by the Second World War, and after it, for example in Poland, they were abolished by the communist authorities. They restarted their activity in 1945, but by the decree on associations of 1949, they were annihilated as were other ecclesiastic organisations ${ }^{6}$.

4 K. Czarnecka, Duchowość ignacjańska nie tylko dla jezuitów, "Studia Bobolanum” 1 (2015), pp. $138-139$.

5 A. Puszka, Sodalicje Mariańskie i ich działalność w Chetmie w latach 1918-1939, in: Chetm nieznany [Ludzie. Miejsca. Wydarzenia], red. M. Karwatowska, Chełm 2009, p. 92.

${ }^{6}$ On the history of the Marian Sodality: com. J. Kochanowicz, Wychowanie w szkołach jezuickich okresu staropolskiego, in: Pedagogika ignacjańska: historia, teoria, praktyka, red. A. Królikowska, Kraków 2010, p. 235; E. Dybowska, Wychowawca w pedagogice ignacjańskiej, Kraków 2013, p. 162; J. Wicki, R. Dendal, Le père Jean Leunis S.J. (1532-1584): Fondateur des 
The sixties and the seventies of the last century brought significant changes, relating to the identity of the Sodality. A part of the Congregation under the care of the Jesuits was transformed into the Christian Life Community. The researches Ewa Czarnecka and Katarzyna Czarnecka, while sketching the genesis of the community, go back further than just to the idea embodied by J. Leunis. They perceive the relationship of the Christian Life Community not only with the Sodality, but also with, in their opinion, its forerunners, who were the people gathered around St. Ignatius of Loyola and his lay associates (also adults), wishing to lead a spiritual life on the basis of the Spiritual Exercises and support the Jesuits in their apostolate 7 . This issue is presented by K. Czarnecka, who suggests that already then the lay people (including those 'of age') constituted the nucleus of the community (adults, among others) in the Sodalities:

the beginnings [of the Marian Sodalities] go back to the times of Ignatius and they still exist, although they have gone through various stages.

Ignatius of Loyola was a spiritual leader of small lay communities before the Society of Jesus was founded, and later he also encouraged his first companions to do so. Such communities were led by Peter Favre in Parma, Francis Xavier in Faenza, as well as Jerome Nadal in Calabria and Ignatius himself in Rome in 1547 — the Association of the Twelve Apostles ${ }^{8}$.

As K. Czarnecka suggests, not referring however to any specific sources (just like E. Dybowska), the Marian Sodality was supposed to evolve somehow out of those groups?.

Congrégations Mariales, Rome 1951; J. Hochleitner, Jezuici $w$ dominium warmińskim na przetomie XVI i XVII wieku, "Studia Warmińskie" 41-42 (2004-2005), pp. 276-277; K. Czarnecka, Duchowość..., pp. 138-139; Sodalicja mariańska, in: Encyklopedia wiedzy o jezuitach na ziemiach Polski i Litwy 1564-1995, red. L. Grzebień, Kraków 1996, p. 629; L. Grzebień, Dzieje kulturalne jezuitów toruńskich (1596-1996), in: Jezuici w Toruniu 1596-1996, red. K. Maliszewski, W. Rozynkowski, Toruń 1997, pp. 73-74; idem, Historiografia jezuickiego wychowania w środkowej $i$ wschodniej Europie, in: Ratio Studiorum 400: The Past, Present and Future of a Four Hundred Year Tradition of Jesuit Education, Kraków 2006, p. 120; idem, Znaczenie jezuitów w Rzeczypospolitej na przetomie XVI i XVII w., "Studia Bobolanum" 3 (2010), p. 44; T. Jeż, Kultura muzyczna jezuitów na Śląsku i ziemi kłodzkiej (1581-1776), Warszawa 2013, p. 241; T.M. Rodrigues da Fonseca Rosa, História da Universidade Teológica de Évora (Séculos XVI a XVIII), Lisboa 2013, p. 142; J. Łukaszewska-Haberkowa, Wptyw pierwszego pokolenia polskich jezuitów na życie kulturalne i religijne Rzeczypospolitej obojga narodów w latach 1564-1608, Kraków 2014, pp. 56-57; A. Puszka, Sodalicje Mariańskie i ich działalność..., p. 92, 109; eadem, Sodalicje Mariańskie na ziemiach polskich wobec wojny i odzyskania niepodlegtości w 1918 r., "Teka Komisji Historycznej" 15 (2018), p. 46.

7 E. Dybowska, Wychowawca ..., pp. 161-162, 358.

${ }^{8}$ K. Czarnecka, Duchowość..., p. 138.

${ }^{9}$ Ibidem. 
The second half of the twentieth century brought the Sodality back to the roots, but the Ignatian roots, forgotten in the Sodalities reborn after the dissolution. Already Pope Pius XII, who himself was well acquainted with the Ignatian spirituality, after the Second World War became interested in the issue of the Sodality renewal. In his Apostolic Constitution Bis saeculari of 1948, in addition to general guidelines for the apostolate of the laity and confirming the identity of the Sodality by the authority of the Church, he called for the renewal of the authentic Ignatian spirit in the Marian Sodality, pointing mainly to the Spiritual Exercises by St Ignatius of Loyola as an essential source of spirituality. The call demanded a positive response. Two years later, in April 1950, Jesuits assisting the Sodality gathered in the General Curia, and discussed the further fate of the Sodality. They were worried because of losing the Ignatian spirit and hoped for greater commitment of the laypeople in the apostolate. As if to meet the call to renew the Sodality by returning to Ignatian sources, since 1951, beginning from the United States of America, the Spiritual Exercises have been given to the lay people. The Second Vatican Council also contributed to the aforementioned return. Its guidelines were intended to be implemented by creating in Rome with the clergy and laity in mind, the Centre for Ignatian Spirituality. Several years of consultations on the renewal of the Sodality culminated in 1967 in the formulation of new General Rules at the 'Roman' meeting of the Main Council of the World Federation of Marian Sodalities. They replaced the Common Rules of 1910. The new General Rules were approved on the feast of the Annunciation of the Blessed Virgin Mary, on March 25, 1968, the feast of the Marian Sodality, and now the Christian Life Community. One of them says,

By reaching the sources of the Marian Sodalities, we see their origin in the groups of lay people that have developed since 1540 in different parts of the world thanks to the initiative of Saint Ignatius of Loyola and his companions. Therefore, we live our Christian lifestyle in union with those, who preceded us, grateful for their testimony and apostolic work. We are closely related by love and prayer to all who have lived and live with our spirituality, being our friends and intercessors in the Church and simultaneously, supporting the accomplishment of our mission ${ }^{10}$.

Furthermore, the name was changed to: the World Federation of Christian Life Communities.

${ }^{10}$ Zasady Ogólne Wspólnoty Życia Chrześcijańskiego [Uchwalone przez Zgromadzenie Ogólne 7 września 1990. Zatwierdzone przez Stolicę Apostolską 3 grudnia 1990], Warszawa 1991, point. 3. On the genesis of apostolate: com. M. Coll, Le Congregazioni mariane (1563-1773) e le Missioni popolari dei Gesuiti. Due varianti della stessa missione, "Ignaciana Rivista di Ricerca Teologica" 17 (2014), p. 71, 75. 
Contrary to the Marian Sodality, well known for example from the $19^{\text {th }}$ century, the Christian Life Community relied more heavily on Ignatian spirituality in the years 1967-1971. So far, and also today, that spirituality has been the foundation of the community existence and functioning. However, it cannot be denied that the former Sodalities combined the Marian dimension with the Ignatian dimension until the end of that consolidation caused by the dissolution of the Society of Jesus. As it has already been mentioned, the dissolution resulted in transferring some part of the Sodalities to the diocesan clergy and thus, under the jurisdiction of bishops ${ }^{11}$.

It is also worth mentioning, that in 1977 Provincial Superior Tadeusz Koczwara SJ initiated the first Christian Life Community in Poland. It was the Warsaw group 'Saint Joseph', gathering students (that is, adults) who helped sick and disabled people. In 1986 at the World Congress in Loyola (Spain) the native National Community entered the World Christian Life Community. In 1999 the Extraordinary National Assembly approved the statute of the 'Polish' Christian Life Community, and in February 2001 that Community obtained the legal personality in Poland ${ }^{12}$.

\section{Adults in the ranks of the Sodality}

On the early modern map of Jesuit works the most abundant were the student Sodalities. Over time the Jesuit Congregations were also supported by adults. Among them even aristocrats and bishops could be found. An example is the Marian Sodality of the Annunciation of the Blessed Virgin Mary in Nysa, founded in 1924. Except students, also bishops, Charles Habsburg and Balthasar Liesch von Hornau as well as count Georg von Oppersdorff and starost of Głogów, Georg Wetzel belonged to this Sodality. The Głogów Sodality of the Annunciation of the Blessed Virgin Mary (established in 1630) was joined by: Emperor Ferdinand II, Archduke Leopold Wilhelm and Archduchess Cecylia Renata. Moreover, apart from the older students, representatives of the intellectual elite of the city also belonged to it. Honorary sodalists in the Wrocław Congregation, aggregated in 1640 to the Prima Primaria, were, among others, Austrian emperors, the Polish king Jan Kazimierz and Cardinal Johann Heinrich von Frankenberg. It is also worth adding that the positions of rectors in the Wrocław Sodality of the Annunciation of the Blessed Virgin Mary were also held by bishops and canons,

${ }^{11}$ More on this issue: com. L. Paulussen, God works like that: Origins of the Christian Life Community, Rome 1979; Sodalicja Mariańska, pp. 629-630; T. Uszyński, Sodalicje Mariańskie, in: Leksykon duchowości katolickiej, red. M. Chmielewski, Lublin-Kraków 2002, pp. 825-828.

${ }^{12}$ K. Czarnecka, Duchowość..., pp. 140-141. 
for example Johannes Scheffler and Andreas Scultetus, the abbots of the nearby monasteries, for example the Grand Master of the Crusader Order, Matthias Daniel Schlecht and the abbot of Augustinians in Żagań, Johann Ignaz von Felbiger, as well as imperial dignitaries, for example counts Johann Anton von Schaffgotsch and Otto von Nostitz ${ }^{13}$. These adults, most often coming from the elites or constituting the elites, joined the Sodalities willingly in the $17^{\text {th }}$ century and in the first half of the $18^{\text {th }}$ century, that is in the era of the especially lush development of the Congregation. Apart from them, in the ranks of the Congregation there were also townspeople, craftsmen, soldiers and servants ${ }^{14}$.

After the revival of the Society of Jesus, in 1814, the Sodality was adopted to new needs of the transforming reality thanks to the laws issued from the mid-19 $9^{\text {th }}$ century to the pre-war period by the generals of the order. Due to the transformations in the social structures a division was made in the Congregation. Its consequence were Sodalities gathering adults and among them: ladies and separately lords (e.g. from the country), landlords, male and female intelligentsia, teachers (men, and separately women, from the country), merchants, factory workers (men and women), craftsmen, craftswomen, women office workers, nurses, servants, fathers, mothers, Polish ladies, German ladies, landladies, monks, women's clothing workers, women workshop workers, men working in the industry and trade, handymen, railroad workers etc. For example in the Jesuit Boarding School in Chyrów (now Ukraine) there was the Sodality of teachers whose priority was to make people from the villages and cities nationally aware, and in the capital city of Małopolska they founded the Sodality of teachers from the Cracow cir$\mathrm{cle}^{15}$. As an example of the Congregation associating adults, it would be worth recalling the Sodality of schoolgirls brought up by the nuns of the Congregation Sacré-Cœur founded in 1875 in Lviv or the Sodality of Cracow ladies in 1886. At the end of the $19^{\text {th }}$ century and the beginning of the $20^{\text {th }}$ century in Cracow, there were as many as a dozen Sodalities, which included adults, such as the Male Intelligentsia, the Merchants, Priests of the Diocese of Cracow, the Townsmen and Lady-teachers ${ }^{16}$. This type of the Sodalities, associating adults, was defined by Henryk Haduch as the type comprising focused adults, divided into the Sodalities of the intelligentsia, factory workers and people who did not live together

13 Ibidem, p. 242. The presence of elites in the Sodality, e.g. city elites, was certainly connected with their cooperation with the Jesuit college, and included, among others, processions and musical setting for liturgical ceremonies, while the presence in the Congregation for example of the aristocracy also raised the prestige of the Sodality, resulting in the wealth of the Sodality pouch, which covered, among others, the costs of organizing services. Ibidem.

14 A. Puszka, Sodalicje Mariańskie i ich działalność..., p. 92.

15 Ibidem, pp. 92-93. Eadem, Sodalicje Mariańskie na ziemiach..., p. 48.

${ }^{16}$ K. Krzysztofek, Sodalicje mężczyzn w Krakowie na przełomie XIX i XX w., "Studia z Prawa Wyznaniowego" 16 (2013), p. 138. 
(division from 1914) ${ }^{17}$. However, father Romuald Moskała, a Jesuit who was the National Promoter of the Sodalities, the forefront of the Nazi occupation, in 1939 described the adults from various circles of the Cracow community joining the Congregations in the following way

Intelligents, belonging to all social spheres of our nation. Under the Sodality banner there are the representatives of the oldest aristocracy and the descendants of middle-class families, as well as the sons of the people. Among us there are dignitaries, a whole range of ministerial advisers and senior state officials from almost all departments, there are Polish army generals in active service and almost the whole staff of active officers in the number of several dozen, there are university professors - all Polish universities have got their representatives in the Sodalities, there are presidents and vice-presidents of various categories of Polish courts, the whole team of court advisers, beginning with the supreme tribunal and ending with the town courts, there are engineers, doctors and freelancers, there are journalists and editors, there are academic young people reaching up to 2,000 members in the Sodalities ${ }^{18}$.

A Jesuit, Jan Rostworowski, wrote about the presence of adults in the Sodalities in the modern era up to the present day similarly, but also with the poetic twist,

those were numerous and strong sodalities, which literally entwined the entire Catholic world of the time and encompassed all its states with the golden network of the Marian organisation. We can see [...] sodalists on papal and imperial thrones, we can see a lot of kings and princes, army chiefs and provincial governors, bishops and mighty landlords, great scientists and famous artists, and above all many Saints. The following Sodalities are founded: clergy and gentry, soldiers and middle-class men, students and craftsmen, servants of the lowest ranks, sailors, fishermen and crafts practitioners. And in all of these sodalities such virtues flourish that the times of the beginning of Christianity are remembered. The ardent love of the Blessed Virgin Mary, deep piety, building the purity of life, mortification to the limits of heroism, active charity manifested not only in generous mercy, but also in willing forgiveness of wrongs and traumas - these are the wonderful flowers out of this world, which fill those sodality classes with their fragrance and intertwine for the congregation into a wreath of immortal glory ${ }^{19}$.

${ }^{17}$ H. Haduch, Zasadnicze typy sodalicyi, in: Przewodnik Sodalicyi Maryańskich złaczonych kanonicznie z Sodalicya Rzymska Prima Primaria zostajacych pod opieka zakonu OO. Jezuitów: Ustawy zasadnicze i sposób prowadzenia sodalicyi, red. H. Haduch, Kraków 1914, pp. 215-230.

${ }_{18}$ R. Moskała, Kim jesteśmy i czego chcemy? Rzecz o Sodalicjach Mariańskich, Kraków 1933, p. 5: http://sodalicja.pl/strona.7571.html [access: 19.08.2020].

19 J. Rostworowski, Przewodnik Sodalicyj Mariańskich złaczonych kanonicznie z Archisodalicja Rzymska zwana Prima Primaria, Warszawa 194633 , pp. 15-16 [post-war edition]. 
It should also be pointed out that in the Greek Catholic Church there were Marian Sodalities associating adults as well.

However, it also happened that an exception was made to admit adults from a particular milieu to the Sodality. An example can be the Cracow Sodality of merchants. The first Congregation destined for the merchant class was founded by Jesuits in Cracow in 1619, and it survived until 1773, i.e. until the dissolution of the Society of Jesus. In December 1885 an idea of that Sodality revival appeared, implemented then in 1886. Afterwards, on March 25 in the church of St Barbara, there was the service establishing the Cracow Sodality of Merchants. In the same year the authorities of the Sodality decided to admit also people who did not belong to the merchant class. The decision resulted in the admission to the Merchant Sodality in Cracow: Prince Adam Stefan Sapieha, Count Konstanty Przeździecki, Count Scipion, Count Józef Badenia and Count Chomentowski ${ }^{20}$. Although the Sodalities had already existed since the $16^{\text {th }}$ century, only after their dissolution, they transformed into church state and social associations, and from the 1830s on they became the essential and successful tool of the pastoral influence ${ }^{21}$.

\section{Formation in the Marian Sodality and its reception in the Christian Life Community}

Originally, it was assumed that the Marian Sodality would combine science with an active Christian life, therefore the first Congregations brought together learners. Anyway, in every Jesuit college there was the Sodality: in Poland, as initiating the history of native Congregations, there was the Marian Sodality in Braniewo (1571). The fundamental content of the educational program in the Sodalities was teaching subordinated to the religious formation, constituting an equal element of the motto of Jesuit dormitories: pietas et litterae ${ }^{22}$. The Sodalities about which Ricardo G. Villoslada writes as "like war camps in the vast field of Catholic Renewal' ${ }^{23}$, shaped religiously, morally and civically, and also sensitized to human poverty, both spiritual and material. This formation included not only young people studying in colleges, but also adults entering the Sodalities.

\footnotetext{
${ }^{20}$ K. Krzysztofek, Sodalicje..., p. 142.

${ }^{21}$ A.P. Bieś, Reaktywacja. Jezuici między ciagłościa a zmiana po 1814 roku, "Studia Bobolanum" 1 (2015), p. 61.

${ }^{22}$ T. Jeż, Kultura ..., p. 394.

23 "Tutte erano come accampementi di guerra nell'ampio della Restaurazione cattolica": R. García Villoslada, Storia del Collegio Romano dal suo inizio (1551) alla soppressione della Compagnia di Gesù (1773), Rome 1954, p. 131.
} 
Furthermore, the membership in the Sodalities was considered an honour ${ }^{24}$ while the guiding slogan of the Congregation was the Latin phrase: Per Mariam ad Jesum ('Through Mary to Jesus').

Without being supported by real life examples, all the rules used in that formation would be pointless or doubtful when it comes to their effectiveness, hence the aforementioned father J. Rostworowski in these words appealed in the following way in his Guidebook, intended for - also adults - sodalists, men and women,

sodality indeed is the key to heaven, a pledge of countless God's grace and a powerful weapon in the fight for the Kingdom of Christ, but it is all this only when the name of a sodalist is followed by loyalty to the rules of the Sodality and life practice worthy of an outstanding servant of the Blessed Virgin Mary ${ }^{25}$.

The sodalists, men and women, could demonstrate their knowledge of these rules in practice, being engaged not only in corresponding sections of the Congregation, such as, for example the eucharistic, Living Rosary, missionary, lecture or mercy, but also showing the authentic, Christian attitude in their everyday environment, for example when included in the missionary section, they supported in prayers and materially, and in the mercy section they met the temporal needs of the poor, visited prisoners and took care of their families ${ }^{26}$. In each case, sensitivity and love for God were formed, as well as sensitivity and love towards the other person, combined with the will to help others.

There were also appropriate guidebooks in Sodality circles that favoured the guidelines contained in them, for example the formation of a model sodalist. These were, for example, instructions published by the Student Sodality founded in 1690 on the initiative of Veit Scheffer, bearing the name: The Academy of God's love, which was in fact literary and publishing brotherhood. Yet another, more recent guidebook was written by father J. Rostworowski, Sodalicyj Mariańskich złaczonych kanonicznie z Archisodalicja Rzymska zwana Prima Primaria (Marian Sodalities joined canonically with the Roman Archisodality called Prima Primaria), whose post-war edition is used by the author of this article. These and other Sodality guides abound, regardless of the space-time in which they were created, with various demands appropriate to the state, for example priests associated in the Congregation were to fruitfully strive for sincere and simple piety, reasonable and persistent diligence, obedience, especially towards the clerical authority, and to be righteous in relations with other people and oneself ${ }^{27}$.

\footnotetext{
${ }^{24}$ Com. T.M. Rodrigues da Fonseca Rosa, História..., p. 142.

25 J. Rostworowski, Przewodnik..., p. 163.

${ }^{26}$ Com. A. Puszka, Sodalicje Mariańskie i ich działalność..., p. 102.

27 K. Krzysztofek, Sodalicje..., p. 139.
} 
A number of recommendations, implemented on a daily basis by sodalists, including adults, were included by father J. Rostworowski in his Guide, starting from the necessity of spiritual 'development', the school of which is the Sodality. In the process of this 'development' he emphasized and recommended daily abiding in the state of sanctifying grace, as well as grasping by faith not only the brain, but also the will and heart. The achievement of these goals made it possible for the Sodalists to follow the rules clearly defined on the pages of the Guide, which was also the goal of the whole formation (education combined with self-education) of adult members of the Congregation.

Based on the rules (listed below), the Sodality taught the basic tools of the 'spiritual fight and inner progress', i.e. the examination of conscience and prayer (especially contemplation as the way leading most directly to God), and recommended reading 'spiritual books', receiving sacraments frequently and 'recollecting the soul in front of God in the annual, if possible, closed retreat ${ }^{28}$. Completing the spiritual tasks guaranteed the acquisition of the virtues or their strengthening. Among them father J. Rostworowski distinguished: chastity, abstinence, honesty, spiritual poverty and piety (the so-called individual virtues), as well as the civil courage, prudence in word, and especially active love of one's neighbour 'which alone opens the door of hearts (the so called 'more social virtues') ${ }^{29}$. The sodalists, regardless of their age, were to acquire Christian virtues 'especially pleasant to Mary' which, according to the aforementioned Jesuit, were: spiritual purity as the consequence of the lack of 'moral dirt', modesty in life, detachment of the heart from excessive attachment to worldly goods, as well as humility and Christian meekness being the base of real love for one's neighbour and a pledge of social peace and harmony. Furthermore, the sodalists were obliged to perfect in themselves such qualities as, for example, the ability to speak and influence people, efficiency in organizational work, as well as discipline and collective conscientiousness, 'without which even the most individual efforts are in vain or are less fruitful than they could be'. Moreover, understandably, they were required to believe in all what the Church revealed and in what the Church commands us to believe, as well as being faithful to its teachings and being able to discern what is right and what is wrong. Father J. Rostworowski writes, '[a sodalist] will strive to develop in himself this Catholic heart, which like some kind of an instinct can distinguish falsehood from truth and sense every danger of faith ${ }^{30}$. What is more and not surprising, the sodalist was required to be exemplary in keeping the commandments of God and was obliged to deepen their knowledge and to defend the Catholic truth, rights and views of the Catholic Church. Moreover, the following

\footnotetext{
${ }^{28}$ J. Rostworowski, Przewodnik..., p. 59.

${ }^{29}$ Ibidem, p. 62.

${ }^{30}$ Ibidem, p. 157.
} 
recommendation of father J. Rostworowski was inherent in the formation and spiritual and moral self-education: '[a sodalist] will not support any bad company, he will not read or keep books and magazines that are contrary to faith and morality ${ }^{31}$. Obviously, every sodalist was also obliged to ardent love and eminent worship for the Blessed Virgin Mary ${ }^{32}$. It has been still practised, especially in Marian Sodalities (in Poland from the centre at Jasna Góra and under the care of the Paulites) which are of the same origin but retained the old name and stricte Marian charism as opposed to the Christian Life Community where Mary is only one aspect of its spirituality. The worship of Mary practised by a sodalist was expressed in sodalite and Marian prayers (especially in the Rosary, Hours of the Immaculate Conception of the Virgin Mary and the Angelus prayer), as well as in celebrating Marian feasts, doubling the Marian cult in May and October, reading about Mary, and even having at home artistic images of the Mother of God ${ }^{33}$.

The spiritual and moral formation of a sodalist consisted of certain practices of the inner life. The Guide of father J. Rostworowski recommended combining every evening prayer with at least a few minutes' examination of conscience, and the morning prayer with a quarter of an hour of meditation. He also encouraged a sodalist to even temporary 'spiritual reading' and what is evident, to the annual, careful three-day retreat, preferably 'closed', that means in silence. The sodalist was also to commune frequently, even every day, attend Holy Mass every day, and confess whenever their conscience demanded it and have the permanent confessor. The sodalist was encouraged to make and implement resolutions and practices important to their spiritual existence. In addition, the character of the sodalist was shaped by, for example, participating in joint work and caring for cordial fraternal relations with other sodalists, also outside the sodality meetings. Furthermore, father J. Rostworowski did not so much dissuade as he forbade certain attitudes that collided with an authentic Christian attitude. Among them he included stubborn adherence to one's opinion, long discussions, gossiping and backbiting, selfishness and conceit, a spirit of criticism and 'an exorbitant point of honour'. He also required from the sodalist to engage in apostolic activity (including, for example, Catholic social work, charity, 'pious work' and others, according to the needs). He believed that a well-formed sodalist would care about keeping or animating the Christian spirit not only in their own families, but also in their own state. Moreover, they were supposed to strengthen the weak in faith, lead the lost to the straight path, reconcile the conflicting ones, encourage the discouraged, engage skilled but not active in the 'Catholic Action', recruit others to the Sodality and consult the authorities, for example, on the issue of defending

\footnotetext{
31 Ibidem.

32 Ibidem.

33 Ibidem, p. 158.
} 
the truth ${ }^{34}$. The guidelines, collected in a small volume have shaped the attitude of members of the Congregation, including adults, without losing anything of its topicality even today.

A lot of these guidelines even today shape the attitude of the members, men and women, in the Christian Life Community (the successor of the Sodality) with spiritual care of Jesuits. Within its framework, spiritual, moral and intellectual formation and self-formation are realized and the Ignatian dimension is connected with the Marian dimension, and dominates over it. Anyway, Ignatianness is Marian. In the formation and self-formation carried out by the Christian Life Community, the 'Spiritual exercises' of St Ignatius of Loyola are considered the priority basis. In the context of the Marian dimension of Ignatianness, it should be emphasized here that the Mother of God is the first and the most important 'retreat' as first, she fully and most perfectly experienced the mysteries of the life of Jesus Christ, forming the foundation for meditation of the four Weeks of, the Ignatian retreat, based on the above mentioned 'Spiritual exercises'. Moreover, Mary was and is the spiritual and moral model for sodalists, men and women, forming the Christian Life Community, but marginalized in the circles of the Community, in contrast to the Marian Sodality with the centre at Jasna Góra.

The formation and self-formation in the Christian Life Community are supported by mutual drawing of spiritual and moral wealth from sources and experience (common prayer, sharing the faith and life) as part of meetings held in basic communities organized at least twice a month, based on the dynamics of the above mentioned 'Spiritual exercises'. Moreover, adult members of the Christian Life Community, every year take part in the Ignatian retreat in silence, the Ignatian retreat 'in life', in sessions and seminars. The essence of their spirituality is to discern, with the help of God's Grace, where God is present in everyday life and what $\mathrm{He}$ calls them for at a particular moment ${ }^{35}$. The formation also gathers the leaders of the Christian Life Community for example the animators (among others, at the School of Leaders at the Academic Chaplaincy of the Catholic University of Lublin) or, for instance, persons who are to accompany their participants in the Ignatian retreat (among others, special courses organized in Warsaw and Poznan), etc. It can be said that the core part of the formation and self-formation and somehow the remnant of the Marian Sodalities, is also the involvement of adult members of the Christian Life Community in helping the poor, persecuted, people in need, remaining on the margins of society (charity dimension of the charism).

The formation and/or self-formation does not end but still exists, even for the whole life. In fact, the continuous formation is even advised to remain in an

\footnotetext{
${ }^{34}$ Ibidem, pp. 159-162.

${ }^{35}$ Ibidem. Com. ibidem, p. 142.
} 
appropriate, apostolic form and therefore, to be ready to answer for yourself what should be done for Jesus Christ. Anyway, every Christian formation, undoubtedly also of adults, and not only within the Marian Sodalities or the Christian Life Community, was and it still is de facto a Christocentric formation, having one goal: to achieve the Christian perfection, i.e. the holiness.

In the context of the above considerations it is not difficult to notice that the face of the Christian Life Community has partially changed, as the follower of the Jesuit Marian Sodality, although many elements coincide or overlap in terms of the meaning and form. Furthermore, the Christian Life Community can be referred to as a community of adults. Ignatian spirituality is not simple or naive, and therefore requires great maturity. This article is not exhaustive, and thus, it has been treated only as the contribution to the issue of the presence of adults in Marian Sodalities before and after the dissolution of the Society of Jesus. Some issues that could enrich the knowledge of the past and present of the Marian Sodality and the Christian Life Community require further research. These issues include the following aspects: to what extent the Christian Life Community retains the dynamics of the Marian Sodality today and what the convergent elements of Ignatian pedagogy with the formation and self-formation in the Christian Life Community are. Moreover, it would be worthwhile to create a complete monograph on the history of the Marian Sodality and Christian Life Community in the past and present, e.g. in Poland and not only here. That would be one more important link in the chain 'yesterday and today' of the Church, the lack of which is perceptible and even calls for joint 'scientific response'.

\section{Summary}

The Christian Life Community is the successor of the Sodality of Our Lady. The Christian Life Community today is mostly made up of adults. They are formed spiritually and morally. This formation had already existed since the beginning in the Sodality of Our Lady, that is since the foundation of the first Sodality of Our Lady by the Jesuit John Leunis in 1563 at the Collegium Romanum. The adults who co-created the Sodality of Our Lady until the $18^{\text {th }}$ century were kings, aristocrats, bishops, nobles, townsmen, craftsmen, servants, but the presence of adults most fully developed after the reactivation of the Society of Jesus (1814). The indications presented in the Guide by the Jesuit Jan Rostworowski have shaped the characters and attitudes of the adult members of the Marian Sodalities for centuries.

\section{Keywords}

Sodality of Our Lady, Christian Life Community, adults, formation, history 


\section{Obecność i formacja osób dorosłych w Sodalicjach Mariańskich. Przyczynek do historii rodzimej}

\section{Streszczenie}

Sukcesorką Sodalicji Mariańskiej jest Wspólnota Życia Chrześcijańskiego. Tworzą ją ludzie dorośli, którzy są formowani duchowo i moralnie. Taka formacja dokonywała się już w Sodalicjach Mariańskich, tj. od założenia przez jezuitę Jana Leunisa pierwszej Sodalicji w $1563 \mathrm{r}$. w Collegium Romanum. Wśród ludzi, którzy współtworzyli Sodalicję do XVIII w., byli królowie, arystokraci, biskupi, szlachta, mieszczanie, rzemieślnicy, słudzy, ale obecność dorosłych w szeregach Sodalicji najpełniej rozwinęła się dopiero po wskrzeszeniu w 1814 r. Towarzystwa Jezusowego. Wskazania zawarte w Przewodniku jezuity Jana Rostworowskiego kształtowały przez wieki charaktery i postawy dorosłych członków i członkiń Sodalicji Mariańskich.

\section{Słowa kluczowe}

Sodalicja Mariańska, Wspólnota Życia Chrześcijańskiego, dorośli, formacja, historia

\section{Bibliography}

Bieś A.P., Reaktywacja. Jezuici między ciagłościa a zmiana po 1814 roku, "Studia Bobolanum" 1 (2015), pp. 41-62.

Coll M., Le Congregazioni mariane (1563-1773) e le Missioni popolari dei Gesuiti. Due varianti della stessa missione, "Ignaciana Rivista di Ricerca Teologica" 17 (2014), pp. 70-79.

Czarnecka K., Duchowość ignacjańska nie tylko dla jezuitów, "Studia Bobolanum” 1 (2015), pp. 137-145.

Dybowska E., Wychowawca w pedagogice ignacjańskiej, Kraków 2013.

Encyklopedia wiedzy o jezuitach na ziemiach Polski i Litwy 1564-1995, red. L. Grzebień, Kraków 1996.

Flaga J., Bractwa i sodalicje jezuickie w Polsce w 2 pot. XVIII w., "Summarium" 3 (1974), pp. 144-148.

Flaga J., Sodalicje w Polsce przed kasata zakonu, in: Encyklopedia wiedzy o jezuitach na ziemiach Polski i Litwy 1564-1995, red. L. Grzebień, Kraków 1996, pp. 630-631.

Flaga J., Z problematyki jezuickich bractw i sodalicji w XVIII wieku, in: Państwo, Kościót, niepodległość, red. J. Skarbek, J. Ziółko, Lublin 1986, pp. 171-187.

García Villoslada R., Storia del Collegio Romano dal suo inizio (1551) alla soppressione della Compagnia di Gesù (1773), Rome 1954.

Grzebień L., Dzieje kulturalne jezuitów toruńskich (1596-1996), in: Jezuici w Toruniu 1596-1996, red. K. Maliszewski, W. Rozynkowski, Toruń 1997, pp. 55-83. 
Grzebień L., Historiografia jezuickiego wychowania w środkowej i wschodniej Europie, in: Ratio Studiorum 400: The Past, Present and Future of a Four Hundred Year Tradition of Jesuit Education, Kraków 2006, pp. 107-124.

Grzebień L., Znaczenie jezuitów w Rzeczypospolitej na przełomie XVI i XVII w., "Studia Bobolanum" 3 (2010), pp. 37-54.

Haduch H., Zasadnicze typy sodalicyi, in: Przewodnik Sodalicyi Maryańskich złaczonych kanonicznie z Sodalicya Rzymska Prima Primaria zostajacych pod opieka zakonu OO. Jezuitów: Ustawy zasadnicze i sposób prowadzenia sodalicyi, red. H. Haduch, Kraków 1914, pp. 215-230.

Hochleitner J., Jezuici w dominium warmińskim na przełomie XVI i XVII wieku, "Studia Warmińskie" 41-42 (2004-2005), pp. 269-280.

https://www.wbc.poznan.pl/dlibra/results?q=sodalis + marianus\&action=SimpleSearchA ction\&type $=-6 \& p=0$.

https://www.wzch.org.pl/.

Jezuici w Toruniu 1596-1996, red. K. Maliszewski, W. Rozynkowski, Toruń 1997.

Jeż T., Kultura muzyczna jezuitów na Śląsku i ziemi kłodzkiej (1581-1776), Warszawa 2013.

Kochanowicz J., Wychowanie w szkołach jezuickich okresu staropolskiego, in: Pedagogika ignacjańska: historia, teoria, praktyka, red. A. Królikowska, Kraków 2010, pp. 205-237.

Krzysztofek K., Sodalicje mężczyzn w Krakowie na przełomie XIX $i$ XX w., "Studia z Prawa Wyznaniowego" 16 (2013), pp. 137-160.

Leksykon duchowości katolickiej, red. M. Chmielewski, Lublin-Kraków 2002.

Łukaszewska-Haberkowa J., Wpływ pierwszego pokolenia polskich jezuitów na życie kulturalne i religijne Rzeczypospolitej obojga narodów w latach 1564-1608, Kraków 2014.

Morawski K.M., 350 lat duchowej sodalicji wświecie, a wszczególności w Polsce, "Przegląd Powszechny" 205 (1935), pp. 331-340.

Moskała R., Kim jesteśmy i czego chcemy? Rzecz o Sodalicjach Mariańskich, Kraków 1933, p. 5: http://sodalicja.pl/strona.7571.html.

Paulussen L., God works like that: Origins of the Christian Life Community, Rome 1979. Pedagogika ignacjańska: historia, teoria, praktyka, red. A. Królikowska, Kraków 2010. Przewodnik Sodalicyi Maryańskich złaczonych kanonicznie z Sodalicya Rzymska Prima Primaria zostajacych pod opieka zakonu OO. Jezuitów: Ustawy zasadnicze i sposób prowadzenia sodalicyi, red. H. Haduch, Kraków 1914.

Puszka A., Sodalicje Mariańskie i ich działalność w Chetmie w latach 1918-1939, in: Chetm nieznany [Ludzie. Miejsca. Wydarzenia], red. M. Karwatowska, Chełm 2009, pp. 90-109.

Puszka A., Sodalicje Mariańskie na ziemiach polskich wobec wojny i odzyskania niepodległości w 1918 r., “Teka Komisji Historycznej” 15 (2018), pp. 45-59. 
Rodrigues da Fonseca Rosa M.T., História da Universidade Teológica de Évora (Séculos XVI a XVIII), Lisboa 2013.

Rostworowski J., Przewodnik Sodalicyj Mariańskich złączonych kanonicznie z Archisodalicja Rzymska zwana Prima Primaria, Warszawa $1946^{3}$.

Sodalicja mariańska, in: Encyklopedia wiedzy o jezuitach na ziemiach Polski i Litwy 1564-1995, red. L. Grzebień, Kraków 1996, pp. 629-630.

Uszyński T., Sodalicje Mariańskie, in: Leksykon duchowości katolickiej, red. M. Chmielewski, Lublin-Kraków 2002, pp. 825-828.

Wicki J., Dendal R., Le père Jean Leunis S.J. (1532-1584): Fondateur des Congrégations Mariales, Rome 1951.

Zasady Ogólne Wspólnoty Życia Chrześcijańskiego [Uchwalone przez Zgromadzenie Ogólne 7 września 1990. Zatwierdzone przez Stolicę Apostolska 3 grudnia 1990], Warszawa 1991.

trans. Dorota Kołodziejczyk 